\section{Design and Use of Easily Made RNA Size Markers}

BioTechniques 23:612-616 (October 1997)

Several techniques for the analysis of RNA structure or metabolism are based on size determination by electrophoresis in denaturing gels. When electrophoretic separation is performed in polyacrylamide/urea gels, ${ }^{32} \mathrm{P}$ endlabeled DNA fragments are frequently used as size markers. However, DNA and RNA molecules do not migrate at identical rates in this gel system (9). Large RNAs or mRNAs are usually separated in denaturing agarose gels. The ribosomal RNAs (18S or $28 \mathrm{~S}$ ) are commonly used as size markers, but these only provide an approximation of size. An alternative is to visualize three or four mRNAs of known size with cDNA probes, but this is a tedious procedure. More common is the use of commercially available RNA markers that are revealed by staining. However, positioning the stained membrane or gel relative to the autoradiogram is a potential source of error. It appears therefore that none of these commonly used size markers are completely satisfactory, but they are continually used, perhaps because making radioactive RNA size markers is considered laborintensive.

Radiolabeled RNA molecules can be easily made by the in vitro transcription of DNA templates in the presence of $[\alpha-$ ${ }^{32}$ P]UTP (8). DNA templates to make radioactive RNA markers are commercialized by several companies, but these would appear to be of limited use because of the extended size range (5-8 $\mathrm{kb})$. Shorter-range RNA ladders have been described that use either templates made from several plasmids, each linearized with a different enzyme (7), or a single plasmid that generates an RNA containing two cis ribozymes (3). The first method is relatively time-consuming, and the second is limited in the range of size markers produced. We describe the design and use of DNA transcription templates that allow three sets of nested ${ }^{32} \mathrm{P}$-labeled RNA size markers to be made from a single plasmid.

The following criteria were retained to screen plasmids as a potential source for the in vitro transcription templates: (i) transcription should be from the T7 promoter, because this commercially available RNA polymerase is both highly efficient and cost-effective. In our hands, the T7 RNA polymerase is also more stable than the T3 RNA polymerase, and both $\mathrm{T} 7$ and $\mathrm{T} 3$ polymerases are more efficient than the SP6 polymerase; (ii) the templates should be derived from the same plasmid to circumvent eventual variations in the efficiency of the $\mathrm{T} 7$ promoter in different contexts; and (iii) the restriction enzymes used to linearize the plasmids should create $5^{\prime}$ protruding or blunt ends, be readily available from most suppliers and be inexpensive.
The plasmid retained (pXLPP2Ac) was that containing the 1556-bp cDNA of the Xenopus laevis phosphatase 2A catalytic subunit (PP2AC) cloned into the EcoRI site of pBluescript ${ }^{\circledR} \mathrm{KS}(-)$ (Stratagene, La Jolla, CA, USA) (5). Plasmids for in vitro transcription were prepared as described by Bouvet et al. (4). Table 1 lists the restriction enzymes used to prepare the transcription templates and the length of the transcribed RNA for each enzyme. The digested plasmids were extracted with phenol/ chloroform and precipitated with ethanol in the presence of $150 \mathrm{mM}$ $\mathrm{NaCl}$. After solubilizing in water, the templates were mixed in the weight proportions given in Table 1, which are

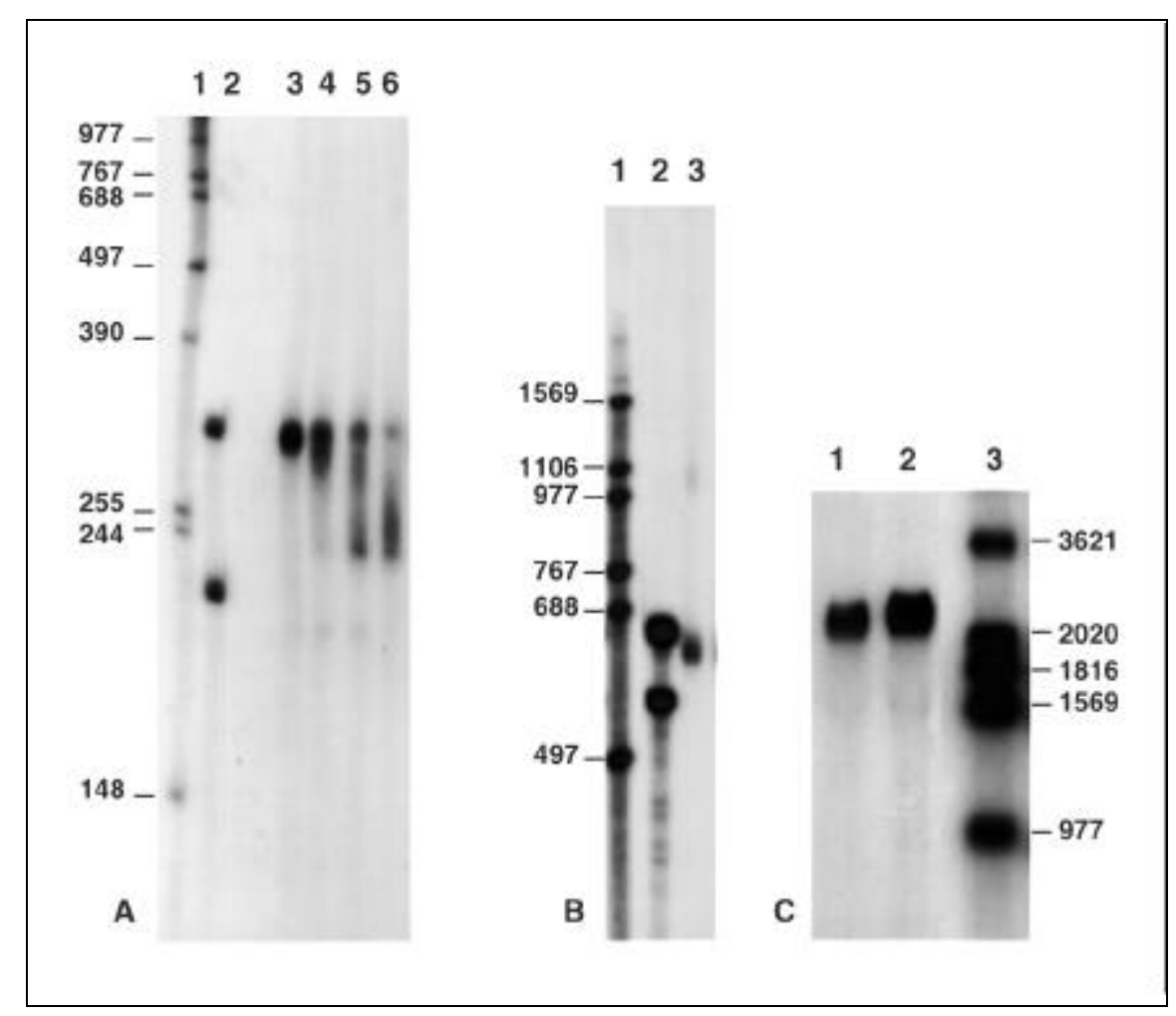

Figure 1. Use of radiolabeled RNAs as size markers. (A) Low-range markers (lane 1) used to analyze the deadenylation of Gbs3'Eg5 RNA injected into X. laevis embryos. This RNA contains the globin 5' untranslated region (UTR) and the last $125 \mathrm{nt}$ of Eg5 $3^{\prime}$ UTR that confers the sequence-specific deadenylation on an RNA (6), followed by a 65-nt adenosine track (4). Non-injected, poly(A) ${ }^{+}$and poly(A)Gbs3'Eg5 RNAs are shown in lane 2. Samples of injected embryos were taken $0 \mathrm{~h}$ (lane 3), $1 \mathrm{~h}$ (lane 4), $2 \mathrm{~h}$ (lane 5) and $4 \mathrm{~h}$ (lane 6 ) after injection. The extracted total RNA (4) was separated by electrophoresis in polyacrylamide/urea gels that were subsequently fixed, dried and autoradiographed. The sizes of the different RNA markers are indicated on the left. (B) Medium-range markers (lane 1) used to determine the length of poly(A) tail added to the 555-nt poly(A)- GbORF RNA (lane 3) by E. coli poly(A) polymerase. Lane 2 shows the migration of the poly(A)- GbORF RNA and a 660-nt RNA used as an internal control. The RNA molecules were analyzed as in Panel A. The sizes of the different RNA markers are indicated on the left. (C) High-range markers (lane 3) used to determine the size of ODC mRNA in unfertilized X. laevis eggs (lane 1) or 4-h embryos (lane 2). Separation was by electrophoresis in a morpholine propanesulfonic (MOPS)/formaldehyde agarose gel. The RNAs were then transferred to a nylon membrane, hybridized with the ${ }^{32} \mathrm{P}$-labeled probe to $X$. laevis ODC and subjected to autoradiography. The sizes of the different RNA markers are indicated on the right. 


\section{Benchmarks}

approximately inversely proportional to the length of the synthesized RNA. The three sets of RNA markers have distinctive patterns (Figure 1) that easily allow band identification even in the case of inadvertently overrun gels. The mixed templates were separated into $1-\mu \mathrm{g}$ aliquots (total template), ethanol-precipitated and stored as alcohol pellets at $-20^{\circ} \mathrm{C}$. By taking these minimal precautions, we have found that in vitro transcription templates can be stored for at least 5 years.

The RNA markers were synthesized as uncapped molecules using $1 \mu \mathrm{g}$ of the mixed templates. The T7 Transcription Kit (Promega France, Charbonnieres, France) was used according to the manufacturer's instructions with $500 \mu \mathrm{M}$ NTP and $10 \mu \mathrm{Ci}[\alpha-32 \mathrm{P}] \mathrm{UTP}$. The synthesized ${ }^{32} \mathrm{P}$-labeled RNA markers were precipitated by $2 \mathrm{vol}$ of ethanol in the presence of $2.5 \mathrm{M}$ ammonium acetate. They were stored at $-20^{\circ} \mathrm{C}$ ready for use after being solubilized in $80 \%$ formamide buffered with $50 \mathrm{mM}$ Tris-borate $(\mathrm{pH} 8.3)$ and $1 \mathrm{mM}$ EDTA. The useful shelf-life of these markers stored at $-20^{\circ} \mathrm{C}$ was at least 3 months and was dictated by the ${ }^{32} \mathrm{P}$ half-life and not by the stability of the RNA molecules. A single transcription reaction produced an amount of RNA marker sufficient for about 500 gels, with two lanes of markers per gel and using an autoradiographic exposure time of several hours.

Figure 1 shows applications for these autoradiograms of the three sets of RNA markers. The autoradiographic data from an experiment using the lowrange markers is shown in Panel A (lane 1). The experimental data (lanes 3-6) illustrate the rapid deadenylation of this Eg5-derived poly(A) ${ }^{+}$RNA injected into $X$. laevis embryos (6). Using the RNA size markers, we calculated that the length of the injected RNA de- creases from 286 nucleotides (nt) to a minimum value of $212 \mathrm{nt}$, which is the size expected for the fully deadenylated transcript.

Panel B shows data from a control in which the medium-size RNA markers (lane 1) were used to measure the length of the poly(A) tail added to an RNA in vitro by the $E$. coli poly(A) polymerase (10). Lane 2 shows the migration of the initial poly(A)- GbORF RNA (1) and of another in vitro-synthesized RNA of $660 \mathrm{nt}$ used as an internal control. Lane 3 shows the migration of the in vitropolyadenylated GbORF RNA. Using the RNA size markers, we calculated that the in vitro-polyadenylated RNAs had a poly(A) tail of $60 \pm 5 \mathrm{nt}$.

The high-range markers are shown in Panel C (lane 3) along with samples of $X$. laevis maternal mRNA (lanes 1 and 2) hybridized with a cDNA probe to ornithine decarboxylase (ODC) mRNA (2). Using the high-range RNA 


\section{Benchmarks}

Table 1. Composition of the Different Sets of RNA Size Markers

\begin{tabular}{|c|c|c|c|c|}
\hline \multirow[b]{2}{*}{ Size (nt) } & \multirow[b]{2}{*}{ Enzyme } & \multicolumn{3}{|c|}{ Proportion in Template Mixture } \\
\hline & & Low & Medium & High \\
\hline 148 & Rsal & 6 & & \\
\hline 244 & Ndel & 4 & & \\
\hline 255 & Dral & 4 & & \\
\hline 390 & $B s t \mathrm{NI}$ & 2 & & \\
\hline 497 & $B g / l$ & 2 & 3 & \\
\hline 688 & Accl & 1.5 & 2 & \\
\hline 767 & Sspl & 1.5 & 2 & \\
\hline 977 & Xhol & 1 & 1.5 & 4 \\
\hline 1106 & BsmAl & & 1.5 & \\
\hline 1569 & Pvull & & 1 & 3 \\
\hline 1816 & HindIII & & & 2 \\
\hline 2020 & Asel & & & 2 \\
\hline 3621 & Scal & & & 1 \\
\hline \multicolumn{5}{|c|}{$\begin{array}{l}\text { The table indicates the size of the RNA synthesized (first column) when the } \\
\text { pBluescript-based pXLPP2Ac plasmid was linearized with the corresponding re- } \\
\text { striction enzyme (second column). The proportions (weight) of the different tem- } \\
\text { plates in the ready-to-use mixtures for the low-, medium- and high-range mark- } \\
\text { ers are indicated in the third, fourth and fifth columns. }\end{array}$} \\
\hline
\end{tabular}

size markers, we calculated that the length of the ODC mRNA was $2100 \pm$ $25 \mathrm{nt}$ in the unfertilized egg RNA sample (lane 1) and $2225 \pm 25 \mathrm{nt}$ in the sample from four-hour embryos (lane 2). The length of this mRNA was previously estimated, relative to the rRNAs, to be $2400 \mathrm{nt}(2)$.

In conclusion, we have described a series of in vitro transcription templates that allow three series of radiolabeled RNA size markers to be produced using well-proven methods and commercially available in vitro transcription kits. The size of these markers ranges from 148 to $3621 \mathrm{nt}$. The transcription templates are derived from the same plasmid and can be stored as a ready-to-use mixture for several years. Therefore, for a laboratory of 5 to 10 research workers, a single large-scale preparation can produce a stock of templates sufficient to reproducibly make these RNA size markers for several years. pXLPP2Ac is available from the authors' laboratory upon request.

\section{REFERENCES}

1.Audic, Y., F. Omilli and H.B. Osborne. 1997. Postfertilization deadenylation of mRNAs in Xenopus laevis embryos is sufficient to cause their degradation at the blastula stage. Mol. Cell. Biol. 17:209-219.
2.Bassez, T., J. Paris, F. Omilli, C. Dorel and H.B. Osborne. 1990. Post-transcriptional regulation of ornithine decarboxylase in Xenopus laevis oocytes. Development 110:955-962.

3.Borneman, J. and M. Altschuler. 1995. Simple method to produce RNA size markers using cis ribozymes. BioTechniques 18:404-406.

4.Bouvet, P., F. Omilli, Y. Arlot-Bonnemains, V. Legagneux, C. Roghi, T. Bassez and H.B. Osborne. 1994. The deadenylation conferred by the $3^{\prime}$ untranslated region of a developmentally controlled mRNA in Xenopus embryos is switched to polyadenylation by deletion of a short sequence element. Mol. Cell. Biol. 14:1893-1900.

5.Cormier, P., H.B. Osborne, T. Bassez, R. Pouhle, R. Bellé and O. Mulner-Lorillon. 1991. Protein phosphatase 2A from Xenopus oocytes. Characterization during meiotic cell division. FEBS Lett. 295:185-188

6.Legagneux, V., F. Omilli and H.B. Osborne. 1995. Substrate-specific regulation of RNA deadenylation in Xenopus embryo and activated egg extracts. RNA 1:1001-1008.

7.Liggit, P., S.-H. Cheng and E.J. Baker. 1994. Generating customized, long-lived ${ }^{32} \mathrm{P}-\mathrm{la}-$ beled RNA size markers. BioTechniques 17:465-468.

8.Melton, D.A., P.A. Krieg, M.R. Rebagliati, T. Maniatis, K. Zinn and M.R. Green. 1984 Efficient in vitro synthesis of biologically active RNA and RNA hybridization probes from plasmids containing a bacteriophage SP6 promoter. Nucleic Acids Res. 12:7035-7056.

9.Sambrook, J., E.F. Fritsch and T. Maniatis. 1982. Molecular Cloning: A Laboratory Manual, 2nd ed. CSH Laboratory Press, Cold Spring Harbor, NY.

10.Wormington, M. 1991. Preparation of synthetic mRNAs and analyses of translational efficiency in microinjected Xenopus oocytes, p. 167-183. In B.K. Kay and H.B. Peng (Eds.), Methods in Cell Biology, Vol. 36. Academic Press, London.

The authors thank R. Hartley for her comments on the manuscript. This work was supported by grants from the European Economic Community, DG12-Biotechnology Program (No. BIO4-CT95-0045), the Ministère Chargé de la Recherche (No. ACC-SV4), the Association pour la Recherche sur le Cancer (Contract No. 6788) and the Ligue National de Lutte Contre le Cancer. Address correspondence to H.B. Osborne, UPR 41 CNRS, Université de Rennes 1, Campus de Beaulieu, 35042 Rennes Cedex, France. Internet: beverley. osborne@univ-rennes1.fr

Received 28 January 1997; accepted 18 April 1997.

Yann Audic, Francis Omilli, H. Beverley Osborne and Laëtitia Landais ${ }^{1}$ Université de Rennes 1 Rennes ${ }^{1}$ Lycee Jean Perrin Reze, France

\section{RT-PCR Detection of RNA Viruses in Stool Specimens}

BioTechniques 23:616-618 (October 1997)

The use of reverse transcription polymerase chain reaction (RT-PCR) to detect viral nucleic acid in stool specimens has been described for both enteroviruses (9) and small round structured viruses (SRSV) $(1,3,7)$. One of the main problems associated with stool RT-PCR is the presence of amplification inhibitors in fecal specimens (5). To overcome this problem, several procedures have been designed that use antigen capture of viral material in stools (6) or specific oligonucleotides attached to magnetic beads that concentrate virus RNA away from the rest of the fecal specimen (8). Other proce- 